\title{
The Substituent Effect on the Addition Course of the Diels-Alder Reaction of 2-Methyl-5-substituted-1,4-benzoquinones with Butadiene
}

\author{
Takashi Harayama, Mitsuaki Ohtani, Masaharu Oki, \\ and Yasuo INUBUSHI
}

Faculty of Pharmaceutical Sciences, Kyoto University 1$)$

(Received April 22, 1972)

\begin{abstract}
The substituent effect on the addition course of the Diels-Alder reaction of butadiene with 2-methyl-1,4-benzoquinones which carry the cyano (V), dimethylcarbamoyl (VI), $\beta$-ethoxycarbonylethyl (VII), $\beta$-cyanoethyl (VIII), ethoxycarbonyl-trans-vinyl (IXa) group at the $\mathrm{C}_{5}$ position, respectively, was examined. The addition of $\mathrm{V}$ and VI occurred one-sidedly at the ethylene linkage carrying the electronwithdrawing cyano and dimethylcarbamoyl group. In the compound (VII and VIII), butadiene added at both ethylene linkages giving a mixture of adducts in the ratio of $\mathrm{XXXIIa/XXXIIb=2/3}$ and $\mathrm{XXXIII} / \mathrm{XXXIIIb}=1 / 1$, respectively. The reaction of 2 -methyl-5-(ethoxycarbonyltrans-vinyl)-1,4-benzoguinone (IXa) with butadiene furnished the adduct (XXXIVa), indicating that the addition occurred at the ethylene linkage bearing the unsaturated ester group.
\end{abstract}

In connection with the synthesis of serratinine $\left.(\mathrm{A}),{ }^{2}\right)$ the compounds (B), of which the angular substituent $R$ carries the $C_{3}$ unit or is capable of extending it to the $C_{3}$ unit, were required to be synthesized by the Diels-Alder reaction of 2-methyl-5-substituted-1,4-benzoquinones with butadiene. To this end the effect of the substituents at $C_{5}$ in several 1,4benzoquinones on the addition course of the Diels-Alder reaction was investigated.

In the Diels-Alder reaction of 1,4-benzoquinones with butadiene, it is known that the addition course of butadiene is affected by the substituent of the benzoquinones. ${ }^{3)}$ Thus, 2-methyl-5-methoxycarbonyl-1,4-benzoquinone (I) bearing the electronwithdrawing group at $\mathrm{C}_{5}$ reacts with butadiene to give the sole addition product (II) possessing the methoxycarbonyl group at the angluar position.4) In addition, Fieser, et al.5) reported that the product from the reaction of 2-methyl- (IIIa) or 2-( $\gamma$-carboxypropyl)-1,4-benzoquinone (IIIb) with butadiene was almost the type (IV) compound. The present paper deals with the results obtained from the Diels-Alder reaction of butadiene with 2-methyl-1,4-benzoquinones which carry the cyano (V), dimethylcarbamoyl (VI), $\beta$-ethoxycarbonylethyl (VII), $\beta$-cyanoethyl (VIII), and ethoxycarbonyl-trans-vinyl group (IXa) at the $\mathrm{C}_{5}$ position, respectively. Further, in order to compare with the result from IXa the reaction of 2 -( $\beta$-ethoxycarbonyl-transvinyl)-1,4-benzoquinone (IXb) bearing no methyl group was also examined. Among these compounds, it is anticipated that the addition of butadiene to the compound (V and VI) will occur one-sidedly at the ethylenic linkage carrying the electronwithdrawing $\mathrm{CN}$ and $\mathrm{CONMe}_{2}$ group in the similar way as the compound (I) and that butadiene will add to the compound (IXa) with some selectivity at the ethylenic linkage bearing the ethoxycarbonyltrans-vinyl group.

1) Location: Yoshida-Shimoadachi-cho, Sakyo-ku, Kyoto.

2) Y. Inubushi, H. Ishii, B. Yasui, M. Hashimoto, and T. Harayama, Chem. Pharm. Bull. (Tokyo), 16, 82, 92, 101 (1968); K. Nishio, T. Fujiwara, K. Tomita, H. Ishii, Y. Inubushi, and T. Harayama, Tetrahedron Letters, $1969,861$.

3) L.W. Butz, "Organic Reactions," Vol. 5, 1949, p. 136; A.S. Onishchenko, "Diene Synthesis," Israel Program for Scientic Translations, Jerusalem, 1964; M.F. Ansell, B.W. Nash, and D.A. Wilson, $J$. Chem. Soc., 1963, 3012.

4) W. Nudenberg, A.M. Gaddis, and L.W. Butz, J. Org. Chem., 8, 500 (1943).

5) L.F. Fieser, M.D. Gates, and G.W. Kilmer, J. Am. Chem. Soc., 62, 2966 (1940). 


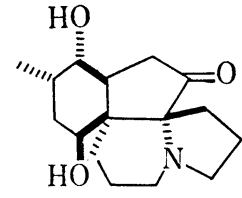<smiles>CC1=CC(=O)C(F)=CC1=O</smiles>

A<smiles></smiles>

I<smiles>[R]C(=O)C=C(C)C(C)=O</smiles>

IIIa $: \mathrm{R}=\mathrm{Me}$

IIIb : $\mathrm{R}=\left(\mathrm{CH}_{2}\right)_{3} \mathrm{CO}_{2} \mathrm{H}$

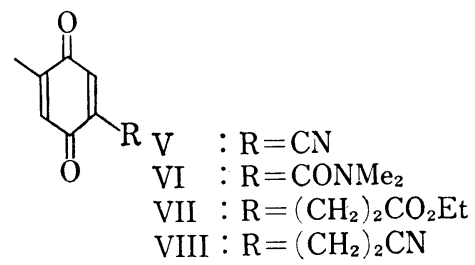

Chart 1<smiles>[R]C1C=CCC2C(=O)C=C(C)C(=O)C12</smiles>

$\mathrm{B}$

\section{Preparation of Quinones}

\section{2-Methyl-5-cyano-1,4-benzoquinone} (V)

2-Methyl-5-methoxycarbonyl hydroquinone $(\mathrm{Xa})$ was benzylated with benzyl chloride and $\mathrm{K}_{2} \mathrm{CO}_{3}$ in dimethyl formamide (DMF) to afford the dibenzyl ether (XI), mp $78-79^{\circ}$, in $90 \%$ yield. Hydrolysis of XI with alkali gave the carboxylic acid (XII), mp $142-143^{\circ}$, which was treated successively with $\mathrm{SOCl}_{2}$ and ammonia gas to provide the amide (XIV), mp 196 $-198^{\circ}$, in $90 \%$ yield from XI. The cyano dibenzyl ether (XV), mp 131 $132^{\circ}$, was obtained by dehydration of XIV with $\mathrm{POCl}_{3}$-pyridine in $93 \%$ yield. Hydrogenolysis of $\mathrm{XV}$ on Pd-C gave quantitatively 2-methyl5 -cyano-hydroquinone (XVI), mp 244 $-246^{\circ}$, which was oxidized with $\mathrm{Ag}_{2} \mathrm{O}$ to give the quinone (V).

\section{2-Methyl-5-dimethylcarbamoyl-1,4-} benzoquinone (VI)

Reaction of the acid chloride (XIII) with dimethylamine gas gave the N-dimethyl amide (XVII), mp $146-148^{\circ}$, in $81 \%$ yield. Debenzylation of XVII gave the hydroquinone amide (XVIII), mp $165-170^{\circ}$, which was oxidized with $\mathrm{Ag}_{2} \mathrm{O}$ to provide the quinone (VI).

\section{2-Methyl-5-( $\beta$-ethoxycarbonylethyl)-1,4-benzoquinone (VII)}

Reduction of XI with LAH gave the primary alcohol (XIX), mp 102-103, which was oxidized with Collins' reagent ${ }^{6}$ ) to furnish the aldehyde (XX), $\mathrm{mp} 120^{\circ}$. The Wittig reaction of XX with diethyl carbethoxymethyl phosphonate ${ }^{7)}$ gave the $\alpha, \beta$-unsaturated ester (XXI), $\mathrm{mp} 101-103^{\circ}$, in $82 \%$ yield from XI. Hydrogenolysis and hydrogenation of XXI afforded the hydroquinone (XXII), mp $79-80^{\circ}$, which was oxidized with $\mathrm{Ag}_{2} \mathrm{O}$ to the corresponding quinone (VII).

\section{2-Methyl-5-( $\beta$-cyanoethyl)-1,4-benzoquinone (VIII)}

The Wittig reaction of the aldehyde (XX) with diethyl cyanoethyl phosphonate gave in $98 \%$ yield the cyano olefine (XXIII), mp 94-96 ${ }^{\circ}$, which was hydrogenated to afford 2methyl-5-( $\beta$-cyanoethyl)-1,4-hydroquinone (XXIV), $\mathrm{mp} 138-139^{\circ}$, in $76 \%$ yield. Oxidation of XXIV with $\mathrm{Ag}_{2} \mathrm{O}$ gave the quinone (VIII).

\section{2-Methyl-5-(2-ethoxycarbonyl-trans-vinyl)-1,4-benzoquinone (IXa)}

Since all attempts to remove the benzyl groups in XXI with various acids were unsuccessful, the methoxymethyl group was chosen as the phenolic hydroxyl-protecting group

6) J.C. Collins, W.W. Hesse, and F.J. Frank, Tetrahedron Letters, 1968, 3363.

7) A.K. Bose and R.T. Dahill, Jr, J. Org. Chem., 30, 5051 (1965); H. Takahashi, K. Fujiwara, and M. Ohta, Bull. Chem. Soc., 35, 1498 (1962); W.S. Wadsworth, Jr and W.D. Emmons, J. Am. Chem. Soc., 83, 1733 (1961). 


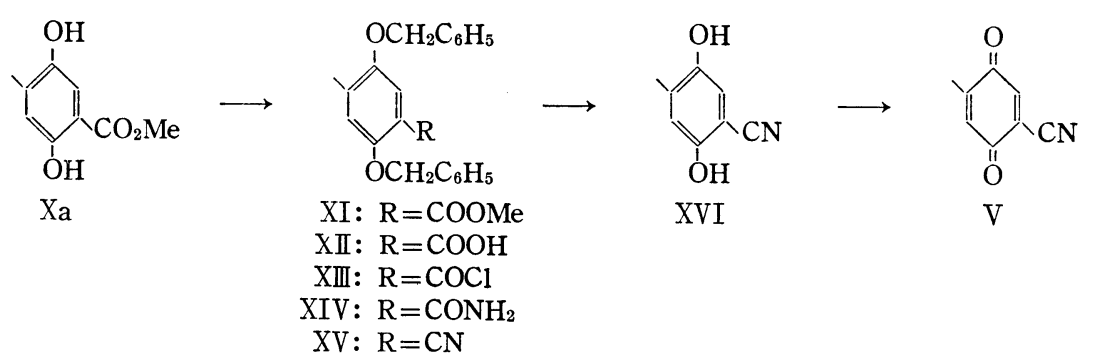

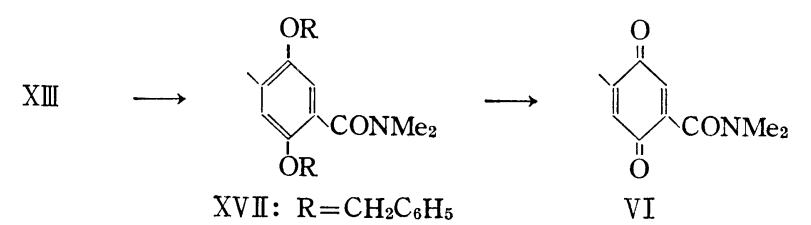

XVIII: $\mathrm{R}=\mathrm{H}$

Chart 2

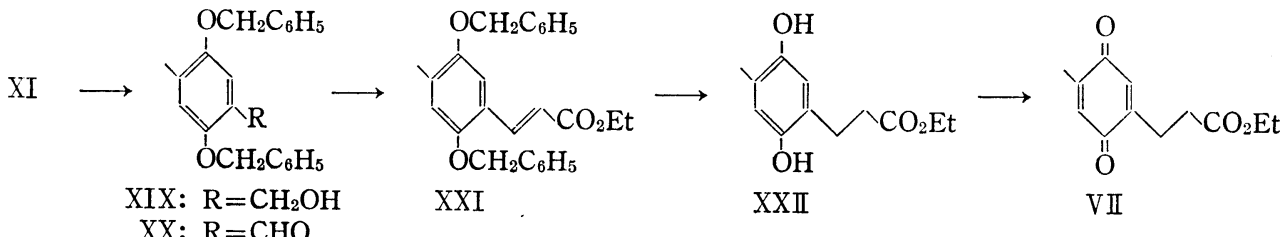

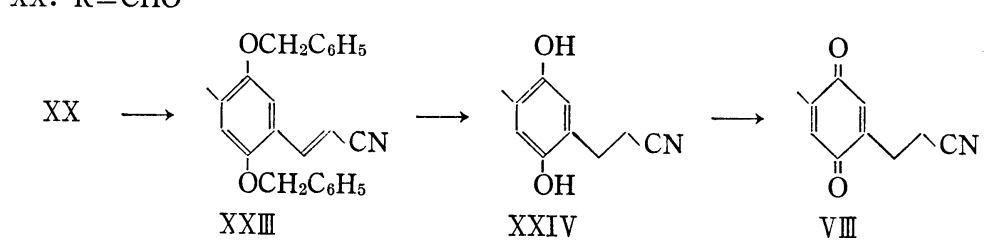

Chart 3

because it is easily cleaved by acids. Thus, treatment of the hydroquinone (Xa) with $\mathrm{NaH}$ and $\mathrm{ClCH}_{2} \mathrm{OCH}_{3}$ in DMF gave the methoxymethyl ether (XXVa) which was reduced to the alcohol (XXVIa), mp 74-75 . Oxidation of (XXVIa) with Collins' reagent afforded the aldehyde (XXVIIa), mp 51-52 $2^{\circ}$, which was derived to the $\alpha, \beta$-unsaturated ester (XXVIIIa), mp $62-63^{\circ}$, by the Wittig reaction with $\mathrm{NaNH}_{2}$ and diethyl carbethoxymethyl phosphonate in THF in $86 \%$ yield from $\mathrm{Xa}$. The nuclear magnetic resonance (NMR) spectrum of (XXVIIIa) showed signals due to trans olefinic protons at $3.57 \tau(1 \mathrm{H}, \mathrm{d}, J=16 \mathrm{~Hz})$ and $2.00 \tau$ $(1 \mathrm{H}, \mathrm{d}, J=16 \mathrm{~Hz})$. Treatment of XXVIIIa with $\mathrm{HCl}$ gave quantitatively the desired hydroquinone (XXIXa), mp 161-163', which was converted to the quinone (IXa) by oxidation with $\mathrm{FeCl}_{3}$ in ethanol.

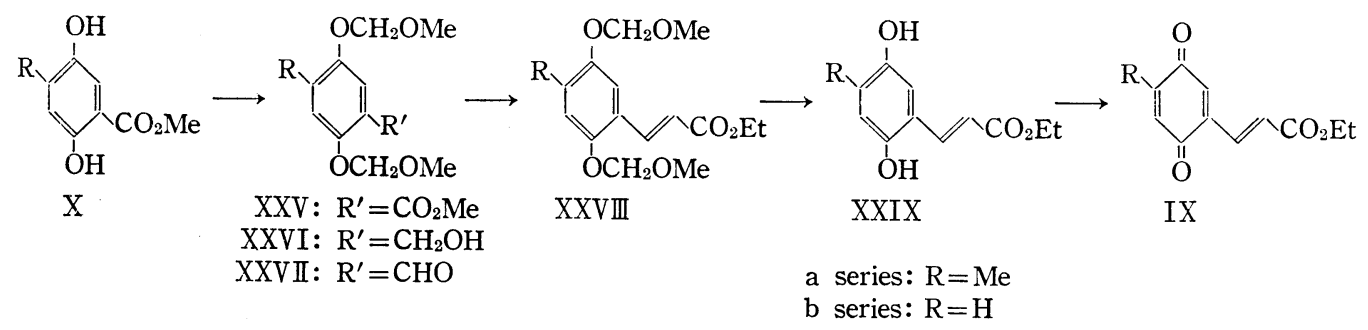




\section{2-(ethoxycarbonyl-trans-vinyl)-1,4-benzoquinone (IXb)}

The compound $(\mathrm{IXb})$ was obtained from 2-methoxycarbonylhydroquinone $(\mathrm{Xb})$ in $55 \%$ yield in analogy with the compound (IXa).

\section{Result and Discussion}

All quinones without any purification were subjected to the Diels-Alder reaction with butadiene in dry benzene.

\section{Reaction of $\mathbf{V}$ with Butadiene}

Treatment of $\mathrm{V}$ with butadiene in a sealed tube at room temperature for two days provided quantitatively the addition product $(\mathrm{XXX}), \mathrm{mp} 85-88^{\circ}$. Its nuclear magnetic resonance (NMR) spectrum exhibited signals due to a vinyl methyl at $7.92 \tau$ (d, $J=1.5 \mathrm{~Hz}$ ) and one olefinic proton at $3.35 \tau(\mathrm{q}, J=1.5 \mathrm{~Hz})$. These spectral data reveal that the addition of butadiene occurred one-sidedly to the ethylene linkage bearing the cyano group.

\section{Reaction of VI with Butadiene}

Heating of VI with butadiene in a sealed tube at $90^{\circ}$ afforded quantitatively the adduct (XXXI) whose NMR spectrum showed signals attributable to a vinyl methyl at $8.00 \tau$ (d, $J=1.5 \mathrm{~Hz}$ ) and one olefinic proton at $3.50 \tau(\mathrm{q}, J=1.5 \mathrm{~Hz}$ ). From this observation the structure of the adduct can be represented by the formula (XXXI), suggesting that the addition of butadiene occurred at the ethylenic linkage carrying the amide group. Under the same reaction condition as that employed in $\mathrm{V}$, a part of the starting material (VI) was recovered unchanged. This fact shows that the dimethylcarbamoyl group causes a decrease in reactivity compared with the cyano group.

\section{Reaction of VII with Butadiene}

Heating of VII with butadiene in a sealed tube at $100^{\circ}$ for $20 \mathrm{hr}$ afforded quantitatively two kinds of adducts which showed one spot on thin-layer chromatography (TLC). In the NMR spectrum, the following signals were observed; $8.70 \tau$ (s, tertiary methyl) and $8.00 \tau(\mathrm{d}, J=1.5 \mathrm{~Hz}$, vinyl methyl). This fact reveals that the adduct is a mixture of XXXIIa and XXXIIb in the ratio of $2 / 3$. Thus, addition of butadiene in this case occurred in two directions.

\section{Reaction of VIII with Butadiene}

Similarly, heating of VIII with butadiene in a sealed tube at $120^{\circ}$ for $20 \mathrm{hr}$ gave quantitatively the adduct (XXXIII), the NMR spectrum of which exhibited a singlet attributable to a tertiary methyl at $8.65 \tau$ and a doublet $(J=1.5 \mathrm{~Hz})$ due to a vinyl methyl at $7.98 \tau$. This fact reveals that the adduct is a mixture of XXXIIIa and XXXIIIb in the ratio of $1: 1$.

\section{Reaction of (IXa) with Butadiene}

The adduct (XXXIVa), mp 114-115\%, was obtained from IXa and butadiene by allowing a reaction mixture to stand overnight at room temperature in $39 \%$ yield. Its NMR spectrum showed signals due to a vinyl methyl at $8.00 \tau(3 \mathrm{H}, \mathrm{d}, J=1.5 \mathrm{~Hz})$ and trans olefinic protons at $4.15 \tau(1 \mathrm{H}, \mathrm{d}, J=16 \mathrm{~Hz})$ and $3.05 \tau(1 \mathrm{H}, \mathrm{d}, J=16 \mathrm{~Hz})$. This observation indicates the one-sided addition of butadiene to an ethylene linkage carrying the $\alpha, \beta$-unsaturated ester group in IXa. Chromatography of the mother liquor from the filtration of the crystalline (XXXIVa) gave a small amount of a yellow substance (XXXV), $\mathrm{M}^{+}$270, mp 90-93, which revealed an ester carbonyl band at $1725 \mathrm{~cm}^{-1}$ and a ketonic band at $1670 \mathrm{~cm}^{-1}$ in the IR spectrum and signals attributable to a vinyl methyl at $7.80 \tau(3 \mathrm{H}, \mathrm{d}, J=1.5 \mathrm{~Hz})$, an olefinic proton at $3.12 \tau(1 \mathrm{H}, \mathrm{q}, J=1.5 \mathrm{~Hz})$ and two benzene protons at $1.75 \tau(1 \mathrm{H}, \mathrm{s})$ and $1.54 \tau(1 \mathrm{H}, \mathrm{s})$ in the NMR spectrum. In addition to these signals, the presence of a vinyl group was shown by signals at $4.42 \tau(1 \mathrm{H}$, d.d, $J=11 \mathrm{~Hz}, J=1 \mathrm{~Hz}), 4.08 \tau(1 \mathrm{H}, \mathrm{d} . \mathrm{d}, J=$ 
$17 \mathrm{~Hz}, J=1 \mathrm{~Hz})$ and $2.50 \tau(1 \mathrm{H}, \mathrm{d} . \mathrm{d}, J=11 \mathrm{~Hz}, J=17 \mathrm{~Hz})$. These results permit to assign the naphthoquinone structure $(\mathrm{XXXV})$ for the yellow substance. Hydrogenation of XXXV on Pd-C furnished the dihydro derivative (XXXVI), $\mathrm{M}^{+} 272, \mathrm{mp} 71-73^{\circ}$, the NMR spectrum of which exhibited signals due to an ethyl group arised from reduction of the vinyl group in XXXV at $8.70 \tau(3 \mathrm{H}, \mathrm{t}, J=8 \mathrm{~Hz})$, and $6.90 \tau(2 \mathrm{H}, \mathrm{q}, J=8 \mathrm{~Hz})$. These results described above can be rationalized by assuming the reaction mechanism as shown in Chart 5. Thus, addition of one double bond of butadiene as a dienophile to the quinone (IXa), followed by dehydrogenation might give the compound (XXXV). Many spots other than those of XXXIVa and XXXV were observed on TLC but no other material was isolated.<smiles>[R]C1=CC(=O)C(C)=CC1=O</smiles>

$\mathrm{V}: \mathrm{R}=\mathrm{CN}$

VI $: \mathrm{R}=\mathrm{CONMe}_{2}$<smiles>[R]C1=CC(=O)C(C)=CC1=O</smiles><smiles>[PH3-]</smiles>

VII $: \mathrm{R}=\left(\mathrm{CH}_{2}\right)_{2} \mathrm{CO}_{2} \mathrm{Et}$

VIII : $\mathrm{R}=\left(\mathrm{CH}_{2}\right)_{2} \mathrm{CN}$<smiles>[R]C1C=CC[C@H]2C(=O)C(C)=CC(=O)C12</smiles>

XXXIIa : $\mathrm{R}=\left(\mathrm{CH}_{2}\right)_{2} \mathrm{CO}_{2} \mathrm{Et} \quad$ XXXII b : $\mathrm{R}=\left(\mathrm{CH}_{2}\right)_{2} \mathrm{CO}_{2} \mathrm{Et}$<smiles>[R]C1=CC(=O)C(=CC=CC(=O)OCC)C=C1</smiles>

IXa $: \mathrm{R}=\mathrm{Me}$

$\mathrm{IXb}: \mathrm{R}=\mathrm{H}$<smiles>[R]C1=CC(=O)C2(CC=CC(=C)C)CC=CCC2C(=O)C1</smiles>

XXXIVa: $\mathrm{R}=\mathrm{Me}$

$\mathrm{XXXIVb}: \mathrm{R}=\mathrm{H}$.<smiles>[R]C1=CC(=O)C2CC=CCC2C1=O</smiles>

XXXIIIb $: \mathrm{R}=\left(\mathrm{CH}_{2}\right)_{2} \mathrm{CN}$<smiles>C=Cc1cc(=O)c2c(cc1=CC(=O)OCC)C(=O)C=C(C)C(=O)C=2</smiles>

Chart 5

\section{Reaction of IXb with Butadiene}

The adduct (XXXIVb), mp $97-98^{\circ}$, was obtained in $28 \%$ yield from IXb in analogy with IXa. Its NMR spectrum showed signals due to an active methine at $6.79 \tau(1 \mathrm{H}, \mathrm{t}$, $J=7.4 \mathrm{~Hz})$ and trans olefinic protons at $4.14 \tau(1 \mathrm{H}, \mathrm{d}, J=16 \mathrm{~Hz})$ and $3.03 \tau(1 \mathrm{H}, \mathrm{d}, J=16$ $\mathrm{Hz}$ ). Consequently, the structure of the adduct should be represented by the formula (XXXIVb), suggesting that butadiene added at the side of the double bond bearing the $\alpha, \beta-$ unsaturated ester group in the quinone (IXb). ${ }^{8)}$

Summarising the above results, the Diels-Alder addition of butadiene with 2-methyl1,4-benzoquinones, (VII and VIII), carrying the saturated side chain at $\mathrm{C}_{5}$, occurred at

8) Although TLC of the mother liquor showed the presence of a yellow substance corresponding to the compound (XXXV) but the isolation of this compound was not achieved. 
both ethylene linkages giving a mixture of adducts in the ratio of XXXIIa/XXXIIb= $2 / 3$ and $\mathrm{XXXIIIa/XXXIIIb}=1 / 1$, respectively. In 2-methyl-benzoquinones, $\mathrm{V}$ and VI bearing the electronwithdrawing substituents at $\mathrm{C}_{5}$, the addition of butadiene occurred one-sidedly at the ethylene linkage carrying these substituents to give quantitatively the adduct, (XXX) and (XXXI), respectively. Further, 2-methyl-1,4-benzoquinone (IXa) with the ethoxycarbonyl-trans-vinyl group at $\mathrm{C}_{5}$ furnished the adduct (XXXIVa), indicating that the addition of butadiene occurred at the side of the ethylene linkage carrying the unsaturated ester group, although the yield was low.

\section{Experimental}

All melting points were observed on a microscopic hotstage and uncorrected. All NMR spectra were obtained in $\mathrm{CDCl}_{3}$ solution with tetramethylsilane as an internal standard on a Varian Associate A-60 recording spectrometer and infrared (IR) spectra were measured for solutions in $\mathrm{CHCl}_{3}$ with $\mathrm{Hitachi}$ EPI spectrometer unless otherwise noted. Mass spectra were taken with a Hitachi RMU-6C spectrometer with a heated direct inlet system.

The Dibenzyl Ether (XI)-CTo a mixture of $9 \mathrm{~g}$ of the hydroquinone $(\mathrm{Xa}), 10 \mathrm{~g}$ of anhydr. $\mathrm{K}_{2} \mathrm{CO}_{3}$ and $20 \mathrm{ml}$ of DMF, $15 \mathrm{~g}$ of benzyl chloride was added dropwise under heating with stirring. After $3 \mathrm{hr}$, the mixture was poured into ice water and extracted with ether. The extract was dried over $\mathrm{MgSO}_{4}$ and evaporated. The residue was recrystallized from petroleum ether to give $16 \mathrm{~g}$ of $\mathrm{XI}$ as colorless pillars, mp $78-79^{\circ}$. IR $\mathrm{cm}^{-1}: v_{\mathrm{c}=0} 1710$. NMR $\tau: 2.40-2.75(11 \mathrm{H}, \mathrm{m}$, benzene protons), $3.13(1 \mathrm{H}$, broad $\mathrm{s}$, benzene proton), $4.90\left(2 \mathrm{H}, \mathrm{s},-\mathrm{OCH}_{2}-\right), 4.95\left(2 \mathrm{H}, \mathrm{s},-\mathrm{OCH}_{2}-\right), 6.12\left(3 \mathrm{H}, \mathrm{s},-\mathrm{COOCH}_{3}\right)$ and $7.70(3 \mathrm{H}, \mathrm{s}$, toluene $\mathrm{Me})$. Anal. Calcd. for $\mathrm{C}_{23} \mathrm{H}_{22} \mathrm{O}_{4}: \mathrm{C}, 76.22 ; \mathrm{H}, 6.12$. Found: $\mathrm{C}, 76.08 ; \mathrm{H}, 6.00$.

The Carboxylic Acid (XII)—To a solution of $2.1 \mathrm{~g}$ of XI in $20 \mathrm{ml}$ of methanol was added a solution of $3 \mathrm{~g}$ of $\mathrm{NaOH}$ in $10 \mathrm{ml}$ of water. The reaction mixture was refluxed for $3 \mathrm{hr}$ on a steam bath, cooled, made acidic with $10 \% \mathrm{HCl}$ and extracted with methylene chloride. The extract was dried over $\mathrm{MgSO}_{4}$ and evaporated to give a crystalline mass. Recrystallization from acetone-ether gave $1.8 \mathrm{~g}$ of XII as colorless prisms, $\mathrm{mp} 142-143^{\circ}$. Anal. Calcd. for $\mathrm{C}_{20} \mathrm{H}_{20} \mathrm{O}_{4}: \mathrm{C}, 75.84 ; \mathrm{H}, 5.79$. Found: $\mathrm{C}, 76.14 ; \mathrm{H}, 5.69$.

The Cyano Dibenzyl Ether (XV)-The reaction mixture of $3.4 \mathrm{~g}$ of the carboxylic acid (XII) in $50 \mathrm{ml}$ of dry benzene and $5 \mathrm{ml}$ of $\mathrm{SOCl}_{2}$ was allowed to stand at room temperature overnight and evaporated to dryness in vacuo. Into a solution of the residue (XIII) in $10 \mathrm{ml}$ of dry benzene was blown $\mathrm{NH}_{3}$ gas. The reaction mixture was diluted with water and extracted with $\mathrm{CH}_{2} \mathrm{Cl}_{2}$. The extract was dried over $\mathrm{K}_{2} \mathrm{CO}_{3}$ and evaporated to leave crude crystals which were recrystallized from acetone- $\mathrm{CH}_{2} \mathrm{Cl}_{2}$ to afford $2.7 \mathrm{~g}$ of the amide (XIV), mp 196-198 ${ }^{\circ}$. To a solution of $2.7 \mathrm{~g}$ of the amide (XIV) in $10 \mathrm{ml}$ of pyridine was added $4 \mathrm{ml}$ of $\mathrm{POCl}_{3}$ under ice cooling. The mixture was allowed to stand at room temperature for 40 minutes, poured into ice water and extracted with $\mathrm{CH}_{2} \mathrm{Cl}_{2}$. The extract was washed with $5 \% \mathrm{HCl}$, dried over $\mathrm{MgSO}_{4}$ and evaporated. The residue was chromatographed on silica gel and elution with $\mathrm{CH}_{2} \mathrm{Cl}_{2}$ afforded $2.4 \mathrm{~g}$ of $\mathrm{XV}$ which was recrystallized from acetone-ether to give colorless prisms, $\mathrm{mp} 131-132^{\circ}$. IR $\mathrm{cm}^{-1}$ : $\nu_{\mathrm{C} \equiv \mathrm{N}}$ 2230. Anal. Calcd. for $\mathrm{C}_{22} \mathrm{H}_{19} \mathrm{O}_{2} \mathrm{~N}: \mathrm{C}, 80.22 ; \mathrm{H}, 5.81$. Found: $\mathrm{C}, 80.17 ; \mathrm{H}, 5.94$.

2-Methyl-5-cyano-hydroquinone (XVI) - To a solution of $2.4 \mathrm{~g}$ of XV in $50 \mathrm{ml}$ of AcOEt was added $200 \mathrm{mg}$ of $10 \% \mathrm{Pd}-\mathrm{C}$. The mixture was stirred under hydrogen at room temperature and atmospheric pressure. After the absorption of hydrogen had ceased, the catalyst was filtered off and the filtrate was evaporated to dryness. The residue was recrystallized from AcOEt to give $1.0 \mathrm{~g}$ of XVI as colorless prisms, $\mathrm{mp} 244-246^{\circ}$. IR cm ${ }^{-1}: \nu_{\text {O-H }} 3300 ; v_{\mathrm{CN}} 2250$ (Nujol). Anal. Calcd. for $\mathrm{C}_{8} \mathrm{H}_{7} \mathrm{O}_{2} \mathrm{~N}: \mathrm{C}, 64.42 ; \mathrm{H}, 4.73$. Found: C, $64.22 ; \mathrm{H}, 4.43$.

The Adduct (XXX)_- To a solution of $400 \mathrm{mg}$ of the hydroquinone (XVI) in $20 \mathrm{ml}$ of dioxane was added $1 \mathrm{~g}$ of dry silver oxide and the mixture was stirred at $45^{\circ}$ for 20 minutes. After cooling, the solid was filtered off and the filtrate was concentrated into dryness to give $300 \mathrm{mg}$ of the quinone V. A solution of $300 \mathrm{mg}$ of $\mathrm{V}$ and $1 \mathrm{~g}$ of butadiene in $5 \mathrm{ml}$ of dry benzene was allowed to stand at room temperature for 2 days in a sealed tube. Removal of the solvent gave $0.36 \mathrm{~g}$ of the crude adduct (XXX) which was chromatographed on silica gel. The eluate with $\mathrm{CHCl}_{3}$ was recrystallized from ether-petroleum ether to afford $(\mathrm{XXX})$ as colorless prisms, $\mathrm{mp} 85-88^{\circ}$. IR $\mathrm{cm}^{-1}: \nu_{\mathrm{CN}} 2260 ; \nu_{\mathrm{C}=0} 1690 ; v_{\mathrm{C}=\mathrm{c}} 1670$ and 1620 . NMIR $\tau 3.35(1 \mathrm{H}, \mathrm{q}, J=1.5 \mathrm{~Hz}$, olefinic proton), $4.22(2 \mathrm{H}, \mathrm{m}$, olefinic protons) and $7.92(3 \mathrm{H}, \mathrm{d}, J=1.5 \mathrm{~Hz}$, vinyl methyl). Anal. Calcd. for $\mathrm{C}_{12} \mathrm{H}_{12} \mathrm{O}_{2} \mathrm{~N}: \mathrm{C}, 71.62 ; \mathrm{H}, 5.51$. Found: $\mathrm{C}, 71.80 ; \mathrm{H}, 5.32$.

The N-Dimethylamide (XVII) - - Into a solution of $1.5 \mathrm{~g}$ of the acyl chloride (XIII) in $50 \mathrm{ml}$ of dry benzene was bubbled $\mathrm{NHMe}_{2}$ gas. The mixture was allowed to stand at room temperature overnight, diluted with water and extracted with $\mathrm{CH}_{2} \mathrm{Cl}_{2}$. The extract was dried over $\mathrm{MgSO}_{4}$. Removal of the solvent left the crude product, which was recrystallized from acetone to provide $1.27 \mathrm{~g}$ of the amide (XVII) as colorless prisms, mp 146-148 . IR cm-1 : $v_{\mathrm{C}=0}$ 1630. Anal. Calcd. for $\mathrm{C}_{24} \mathrm{H}_{25} \mathrm{O}_{3} \mathrm{~N}: \mathrm{C}, 76.77 ; \mathrm{H}, 6.71$. Found: C, $76.62 ; \mathrm{H}, 6.61$. 
2-Methyl-5-dimethylcarbamoyl-hydroquinone (XVIII) - A solution of $150 \mathrm{mg}$ of the amide (XVII) in $10 \mathrm{ml}$ of AcOEt was hydrogenolyzed over $100 \mathrm{mg}$ of $10 \%$ Pd-C at atmospheric pressure and room temperature until the absorption of hydrogen had ceased. The catalyst was removed by filtration and the filtrate was evaporated to dryness. The residue was crystallized from AcOEt to afford colorless prisms (XVIII), mp $165-170^{\circ}$. IR $\mathrm{cm}^{-1}: v_{0-\mathrm{H}} 3350 ; v_{\mathrm{C}=0} 1610$. Anal. Calcd. for $\mathrm{C}_{10} \mathrm{H}_{13} \mathrm{O}_{2} \mathrm{~N}: \mathrm{C}, 61.52 ; \mathrm{H}, 6.71$. Found: $\mathrm{C}, 61.46 ; \mathrm{H}, 6.71$.

The Adduct (XXXI) - To a solution of $560 \mathrm{mg}$ of XVIII in $10 \mathrm{ml}$ of dry benzene and $10 \mathrm{ml}$ of dry dioxane were added $1.1 \mathrm{~g}$ of $\mathrm{Ag}_{2} \mathrm{O}$ and $1 \mathrm{~g}$ of $\mathrm{Na}_{2} \mathrm{SO}_{4}$, and the mixture was stirred at $50^{\circ}$ for 40 minutes. After cooling, the precipitates were filtered off and the filtrate was concentrated to dryness in vacuo to give the quinone (VI). A solution of $470 \mathrm{mg}$ of the quinone (VI) in $6 \mathrm{ml}$ of dry benzene and $2 \mathrm{~g}$ of butadiene was heated in a sealed tube at $100^{\circ}$ for $6 \mathrm{hr}$. The solvent was evaporated under reduced pressure to give $570 \mathrm{mg}$ of the oily adduct (XXXI), $\mathrm{M}^{+} 247$. IR $\mathrm{cm}^{-1}: \nu_{\mathrm{C}=0} 1690$ and 1640 . NMR $\tau: 3.50(1 \mathrm{H}, \mathrm{q}, J=1.5$ $\mathrm{Hz}$, olefinic proton), $4.30(2 \mathrm{H}, \mathrm{m}$, olefinic protons $), 7.05\left(6 \mathrm{H}, \mathrm{s}, \mathrm{NMe}_{2}\right), 8.00(3 \mathrm{H}, \mathrm{d}, J=1.5 \mathrm{~Hz}, \mathrm{vinyl}$ methyl).

The Alcohol (XIX) To a solution of $8.4 \mathrm{~g}$ of the ester (XI) in $200 \mathrm{ml}$ of dry ether was added $2.5 \mathrm{~g}$ of $\mathrm{LiAlH}_{4}$ and the mixture was refluxed for $3 \mathrm{hr}$. Excess hydride was decomposed with AcOEt, followed by addition of wet ether, and the separated organic layer was dried over $\mathrm{MgSO}_{4}$. Removal of the solvent gave $7.7 \mathrm{~g}$ of the crude crystalline mass which was recrystallized from ether and $n$-hexane to afford colorless pillars (XIX), mp 102-103 ${ }^{\circ}$. IR cm-1 : vo-H 3550. Anal. Calcd. for $\mathrm{C}_{22} \mathrm{H}_{22} \mathrm{O}_{3}: \mathrm{C}, 79.01 ; \mathrm{H}, 6.63$. Found: C, $79.02 ; \mathrm{H}, 6.39$.

The Aldehyde (XX)—To a solution of $7.7 \mathrm{~g}$ of the alcohol (XIX) in $600 \mathrm{ml}$ of dry $\mathrm{CH}_{2} \mathrm{Cl}_{2}$ was added $3.5 \mathrm{~g}$ of $\mathrm{CrO}_{3}-2$ pyridine complex and the mixture was stirred for $4 \mathrm{hr}$. The brownish solid was filtered off and the filtrate was washed with water, dried over $\mathrm{MgSO}_{4}$ and evaporated in vacuo. The residue was chromatographed on silica gel. The eluate with $\mathrm{CH}_{2} \mathrm{Cl}_{2}$ was recrystallized from ether to give $7.15 \mathrm{~g}$ of the aldehyde $(\mathrm{XX})$ as pale yellow pillars, $\mathrm{mp} 120^{\circ}$. IR $\mathrm{cm}^{-1}: v_{\mathrm{C}_{-} \mathrm{H}} 2750 ; v_{\mathrm{C}_{2}=0} 1670$. Anal. Calcd. for $\mathrm{C}_{22} \mathrm{H}_{20} \mathrm{O}_{3}$ : $\mathrm{C}, 79.49 ; \mathrm{H}, 6.06$. Found $\mathrm{C}, 79.53 ; \mathrm{H}, 6.20$.

The $\boldsymbol{\alpha}, \boldsymbol{\beta}$-Unsaturated Ester (XXI)-To a stirred suspension of $400 \mathrm{mg}$ of $\mathrm{NaNH}_{2}$ in $10 \mathrm{ml}$ of dry THF was added dropwise a solution of $2.5 \mathrm{~g}$ of diethyl carbethoxymethyl phosphonate in $10 \mathrm{ml}$ of dry THF under ice cooling. Then, the solution was stirred at room temperature under a slow stream of nitrogen to sweep out the evolved ammonia. To the solution was added dropwise $3 \mathrm{~g}$ of the aldehyde (XX) in $10 \mathrm{ml}$ of dry. $\mathrm{THF}$ with stirring at $0-5^{\circ}$. After $1 \mathrm{hr}$, the reaction mixture was diluted with water and extracted with ether. After drying over $\mathrm{MgSO}_{4}$, the solvent was evaporated. Recrystallization of the residue from ether$n$-hexane gave $3.2 \mathrm{~g}$ of the $\alpha, \beta$-unsaturated ester (XXI) as colorless flakes, mp $101-103^{\circ}$. IR $\mathrm{cm}^{-1}: \nu_{\mathrm{C}_{=}} 0$ $1700 ; v_{\mathrm{C}=\mathrm{C}} 1630$. NMR $\tau: 1.95(1 \mathrm{H}, \mathrm{d}, J=16 \mathrm{~Hz}$, olefinic proton $), 3.58(1 \mathrm{H}, \mathrm{d}, J=16 \mathrm{~Hz}$, olefinic proton), $5.75\left(2 \mathrm{H}, \mathrm{q}, J=7 \mathrm{~Hz},-\mathrm{O}-\mathrm{CH}_{2}-\mathrm{CH}_{3}\right), 8.70\left(3 \mathrm{H}, \mathrm{t}, J=7 \mathrm{~Hz},-\mathrm{CH}_{2}-\mathrm{CH}_{3}\right)$.

2-Methyl-5-( $\beta$-ethoxycarbonylethyl)-hydroquinone (XXII) — To a solution of $200 \mathrm{mg}$ of XXI in $15 \mathrm{ml}$ of AcOEt were added $100 \mathrm{mg}$ of $10 \% \mathrm{Pd}-\mathrm{C}$ and a drop of $5 \% \mathrm{HCl}$. The mixture was stirred under hydrogen at room temperature and atmospheric pressure until the absorption of hydrogen had ceased. After removal of the catalyst by filtration, the filtrate was evaporated to leave $110 \mathrm{mg}$ of the hydroquinone (XXII) which was recrystallized from ether-petroleum ether to afford colorless prisms, $\mathrm{mp} 79-80^{\circ}$. IR $\mathrm{cm}^{-1}: v_{0-\mathrm{H}} 3600 ; 3400, v_{\mathrm{C}_{=0}} 1715$. Anal. Calcd. for $\mathrm{C}_{12} \mathrm{H}_{16} \mathrm{O}_{4}: \mathrm{C}, 64.27 ; \mathrm{H}, 7.19$. Found: $\mathrm{C}, 64.07 ; \mathrm{H}, 7.46$.

The Adduct (XXXII) - To a solution of $100 \mathrm{mg}$ of XXII in $20 \mathrm{ml}$ of dry benzene were added $250 \mathrm{mg}$ of dry $\mathrm{Ag}_{2} \mathrm{O}$ and $200 \mathrm{mg}$ of $\mathrm{Na}_{2} \mathrm{SO}_{4}$. The mixture was stirred at room temperature for $1 \mathrm{hr}$ and the precipitates were filtered off. The filtrate was evaporated to leave $90 \mathrm{mg}$ of the yellow oily quinone (VII) which was dissolved in $5 \mathrm{ml}$ of dry benzene. To this solution was added $2 \mathrm{~g}$ of butadiene and the mixture was heated at $100^{\circ}$ in a sealed tube for $20 \mathrm{hr}$. The solvent was evaporated to give $110 \mathrm{mg}$ of the oily adducts which were the mixture of XXXIIa and XXXIIb in the ratio of $2: 3$. IR $\mathrm{cm}^{-1}: v_{\mathrm{C}=0} 1730,1680 ; v_{\mathrm{C}}=\mathrm{C}$ 1625. NMR $\tau: 3.55$ (olefinic proton), 8.00 (vinyl methyl), 8.70 (tetirary methyl). Anal. Calcd. for $\mathrm{C}_{16} \mathrm{H}_{20}$ $\mathrm{O}_{4}: \mathrm{C}, 69.54 ; \mathrm{H}, 7.30$. Found: C, 69.54; H, 7.28.

The Cyano Olefine (XXIII) - To a suspension of $480 \mathrm{mg}$ of $\mathrm{NaNH}_{2}$ in $20 \mathrm{ml}$ of dry THF was added dropwise a solution of $2.1 \mathrm{~g}$ of diethyl cyanomethyl phosphonate in $10 \mathrm{ml}$ of dry THF with stirring under ice cooling. The solution was then stirred at room temperature under a slow stream of nitrogen to sweep out the evolved ammonia. Into the reaction mixture, a solution of $2 \mathrm{~g}$ of the aldehyde (XX) in $30 \mathrm{ml}$ of dry THF was added dropwise at room temperature. After 30 minutes, the reaction mixture was diluted with water and extracted with ether. The extract was dried over $\mathrm{MgSO}_{4}$ and evaporated. The residue was recrystallized from ether-petroleum ether to afford $2.1 \mathrm{~g}$ of the cyano olefine (XXIII), mp $94-96^{\circ}$, as colorless needles. IR cm-1: $v_{\mathrm{CN}} 2230$. NMR $\tau: 2.40(1 \mathrm{H}, \mathrm{d}, J=16 \mathrm{~Hz}$, olefinic proton), $2.62(10 \mathrm{H}$, s., benzene protons), $3.15(2 \mathrm{H}, \mathrm{s}$, benzene protons), $4.11(1 \mathrm{H}, \mathrm{d}, J=16 \mathrm{~Hz}$, olefinic proton), 4.94, 4.96 (each $\left.2 \mathrm{H}, \mathrm{s},-\mathrm{OCH}_{2}-\right)$ and $7.70\left(3 \mathrm{H}, \mathrm{s}\right.$, toluene methyl). Anal. Calcd. for $\mathrm{C}_{21} \mathrm{H}_{21} \mathrm{O}_{2} \mathrm{~N}: \mathrm{C}, 81.10 ; \mathrm{H}, 5.96$. Found: $\mathrm{C}, 81.17 ; \mathrm{H}, 5.75$.

The Adducts (XXXIIIa) and (XXXIIIb)_-To a solution of $1.5 \mathrm{~g}$ of the cyano olefine (XXIII) in $20 \mathrm{ml}$ of $\mathrm{EtOH}$ and a drop of $5 \% \mathrm{HCl}$ was added $500 \mathrm{mg}$ of $10 \% \mathrm{Pd}-\mathrm{C}$. Catalytic reduction as usual gave $570 \mathrm{mg}$ of 2-methyl-5-( $\beta$-cyanoethyl)-1,4-hydroquinone (XXIV) which was labile but could be recrystallized from 
ether-petroleum ether to give colorless flakes, mp 138-139 ${ }^{\circ}$ IR $\mathrm{cm}^{-1}: v_{0_{-} \mathrm{H}} 3100 ; v_{\mathrm{CN}} 2240$ (Nujol). To. a mixture of $340 \mathrm{mg}$ of XXIV, $500 \mathrm{mg}$ of $\mathrm{Na}_{2} \mathrm{SO}_{4}$ and $50 \mathrm{ml}$ of dry ether was added $600 \mathrm{mg}$ of dried $\mathrm{Ag}_{2} \mathrm{O}$. The reaction mixture was stirred at room temperature for $1 \mathrm{hr}$ and after the precipitates were removed by filtration, the filtrate was evaporated to provide $300 \mathrm{mg}$ of the crude quinone (VIII). To a solution of $300 \mathrm{mg}$ of the quinone (VIII) in $5 \mathrm{ml}$ of dry benzene was added $1 \mathrm{~g}$ of butadiene. The reaction mixture was heated in a sealed tube at $120^{\circ}$ for $20 \mathrm{hr}$. Work-up as usual afforded $380 \mathrm{mg}$ of the oily adduct (XXXIII), $\mathrm{M}^{+} 229$, which was shown a mixture of XXXIIIa and XXXIIIb by the following spectral data. IR cm ${ }^{-1}: \nu_{\mathrm{CN}} 2260 ; \nu_{\mathrm{C}=0} 1680$ and $\nu_{\mathrm{C}=\mathrm{C}} 1620$. NMR $\tau: 3.42$ ( $\mathrm{t}, J=1 \mathrm{~Hz}$, olefinic proton), 3.50 (q, $J=1.5 \mathrm{~Hz}$, olefinic proton), 7.98 (d, $J=1.5 \mathrm{~Hz}$, vinyl methyl), 8.65 (s, tertiary methyl).

The Alcohol (XXVIa)_-To a suspension of $25 \mathrm{~g}$ of $\mathrm{NaH}$ (mineral oil free) in $100 \mathrm{ml}$ of DMF was added a solution of $50 \mathrm{~g}$ of the hydroquinone $(\mathrm{Xa})$ in $100 \mathrm{ml}$ of DMF with stirring under ice cooling and nitrogen atmosphere. To the reaction mixture was added dropwise $100 \mathrm{~g}$ of $\mathrm{ClCH}_{2} \mathrm{OCH}_{3}$ during 30 minutes at $0-5^{\circ}$. After excess hydride was decomposed with wet ether, the mixture was diluted with water and extracted with ether. The ether extract was dried over $\mathrm{MgSO}_{4}$ and evaporated to dryness under reduced pressure to give $75 \mathrm{~g}$ of the oily methoxy methyl ether (XXVa). To a solution of $75 \mathrm{~g}$ of XXVa in $450 \mathrm{ml}$ of dry ether was carefully added $9 \mathrm{~g}$ of $\mathrm{LiAlH}_{4}$. After the end of reaction, excess reagent was decomposed with AcOEt and wet ether. The organic layer was dried over $\mathrm{MgSO}_{4}$ and evaporated. Recrystallization of the residue from ether provided $51 \mathrm{~g}$ of the alcohol (XXVIa) as colorless needles, $\mathrm{mp} 74-75^{\circ}$. IR $\mathrm{cm}^{-1}$ : $\nu_{\text {OH }} 3450$. NMR $\tau: 2.97$ (1H, s, benzene proton), $3.10\left(1 \mathrm{H}, \mathrm{s}\right.$, benzene proton), $4.85\left(4 \mathrm{H}, \mathrm{s}, 2 \times \mathrm{O}-\mathrm{CH}{ }_{2}-\mathrm{O}\right)$, $5.35\left(2 \mathrm{H}, \mathrm{s},-\mathrm{CH}_{2}-\mathrm{OH}\right), 6.52\left(6 \mathrm{H}, \mathrm{s}, 2 \times \mathrm{OCH}_{3}\right)$ and $7.76(3 \mathrm{H}, \mathrm{s}$, toluene methyl).

The Aldehyde (XXVIIa)—To a solution of $28 \mathrm{~g}$ of the alcohol (XXVIa) in 1.41 of dry $\mathrm{CH}_{2} \mathrm{Cl}_{2} \mathrm{was}$ added $80 \mathrm{~g}$ of $\mathrm{CrO}_{3}-2$ pyridine complex and the mixture was stirred at room temperature for $2 \mathrm{hr}$. Further, $30 \mathrm{~g}$ of the complex was added and after $2 \mathrm{hr}$, the solid was filtered off and the $\mathrm{CH}_{2} \mathrm{Cl}_{2}$ solution was washed with water and dried over $\mathrm{MgSO}_{4}$. Removal of the solvent in vacuo gave the crude aldehyde which was chromatographed on silica gel. Eluate with $\mathrm{CH}_{2} \mathrm{Cl}_{2}$ was recrystallized from $n$-hexane to provide $26 \mathrm{~g}$ of the aldehyde (XXVIIa) as colorless prisms, mp 51-52 . IR $\mathrm{cm}^{-1}: v_{\mathrm{C}=0}$ 1670. Anal. Calcd. for $\mathrm{C}_{12} \mathrm{H}_{16} \mathrm{O}_{5}$ : C, $59.99 ; \mathrm{H}, 6.71$. Found: $\mathrm{C}, 59.91 ; \mathrm{H}, 6.87$.

The $\boldsymbol{\alpha}, \boldsymbol{\beta}$-Unsaturated Ester (XXVIIIa)_- To a suspension of $4 \mathrm{~g}$ of $\mathrm{NaNH}_{2}$ in $100 \mathrm{ml}$ of dry THF was. added dropwise with stirring a solution of $20 \mathrm{~g}$ of diethyl carbethoxymethyl phosphonate in $50 \mathrm{ml}$ of dry THF under ice cooling. The solution was then stirred at room temperature under a slow stream of nitrogen to sweep out the evolved ammonia. Into the reaction mixture, a solution of $20 \mathrm{~g}$ of the aldehyde (XXVIIa) in $50 \mathrm{ml}$ of dry THF was added dropwise during half an hour at room temperature. The. solvent was removed under reduced pressure and then the residue was taken up in water. The aqueous solution was extracted with ether and the extract was dried over $\mathrm{MgSO}_{4}$. Removal of the solvent left $25.5 \mathrm{~g}$ of the $\alpha, \beta$-unsaturated ester (XXVIIIa) which was recrystallized from $n$-hexane to give colorless prisms, $\operatorname{mp} 62-63^{\circ}$. IR cm ${ }^{-1}: \nu_{\mathrm{C}=0} 1695 ; v_{\mathrm{C}=\mathrm{C}} 1630$. NMR $\tau: 2.00(1 \mathrm{H}, \mathrm{d}, J=16 \mathrm{~Hz}$, olefinic proton), $3.57(1 \mathrm{H}$, $\mathrm{d}, J=16 \mathrm{~Hz}$, olefinic proton), $5.73\left(2 \mathrm{H}, \mathrm{q}, J=7 \mathrm{~Hz}, \mathrm{CO}_{2} \mathrm{CH}_{2} \mathrm{CH}_{3}\right)$, and $8.66\left(3 \mathrm{H}, \mathrm{t}, J=7 \mathrm{~Hz}, \mathrm{CO}_{2} \mathrm{CH}_{2}\right.$ $\left.\mathrm{CH}_{3}\right)$. Anal. Calcd. for $\mathrm{C}_{16} \mathrm{H}_{22} \mathrm{O}_{6}: \mathrm{C}, 61.92 ; \mathrm{H}, 7.15$. Found: $\mathrm{C}, 61.82 ; \mathrm{H}, 7.34$.

2-Methyl-5-(2-ethoxycarbonyl-trans-vinyl)-1,4-hydroquinone (XXIXa)—A solution of $50 \mathrm{~g}$ of the ether (XXVIIIa) in $150 \mathrm{ml}$ of $99 \% \mathrm{EtOH}$ and five drops of conc. $\mathrm{HCl}$ was refluxed for $4 \mathrm{hr}$ under nitrogen. After cooling, the mixture was diluted with a large amount of water and extracted with ether. The ether extract was dried over $\mathrm{MgSO}_{4}$ and evaporated to leave $35 \mathrm{~g}$ of the crystalline mass which was recrystallized from ether-benzene to afford pale yellow needles, mp 161-163 ${ }^{\circ}$. IR cm ${ }^{-1}: v_{\mathrm{O}-\mathrm{H}} 3350 ; v_{\mathrm{C}=\mathrm{O}} 1690 ; v^{\mathrm{C}=\mathrm{C}}$ 1620 (Nujol). Anal. Calcd. for $\mathrm{C}_{12} \mathrm{H}_{14} \mathrm{O}_{4}: \mathrm{C}, 64.85 ; \mathrm{H}, 6.35$. Found: $\mathrm{C}, 64.61 ; \mathrm{H}, 6.34$.

The Adducts (XXXIVa) and (XXXV)—To a stirred solution of $50 \mathrm{~g}$ of the hydroquinone (XXIXa) in $250 \mathrm{ml}$ of $99 \% \mathrm{EtOH}$ was added dropwise a solution of $350 \mathrm{~g} \mathrm{of} \mathrm{FeCl}_{3}$ in $250 \mathrm{ml}$ of $99 \%$ EtOH under ice cooling. After $1.5 \mathrm{hr}$, ether was added and the ether solution was washed with water several times, dried over $\mathrm{MgSO}_{4}$ and evaporated to give $48 \mathrm{~g}$ of the crude quinone (IXa). To a solution of $48 \mathrm{~g}$ of the quinone (IXa) in $50 \mathrm{ml}$ of dry benzene was added $32 \mathrm{~g}$ of butadiene. The mixture was stirred in an autoclave at room temperature overnight and the solvent was evaporated under reduced pressure. When triturated with ether, the residue gave $24 \mathrm{~g}$ of the crystalline mass which was recrystallized from ether to provide colorless prisms (XXXIVa), mp 114-115 . IR cm ${ }^{-1}: v_{\mathrm{C}_{=}=0} 1710,1680 ; v_{\mathrm{C}=\mathrm{C}} 1640,1620$. NMR $\tau: 3.05(1 \mathrm{H}$, $\mathrm{d}, J=16 \mathrm{~Hz}$, olefinic proton), $3.47(1 \mathrm{H}, \mathrm{q}, J=1.5 \mathrm{~Hz}$, olefinic proton), 4.15 (1H, d, $J=16 \mathrm{~Hz}$, olefinic proton), $4.30\left(2 \mathrm{H}, \mathrm{m}\right.$, olefinic protons), $5.80\left(2 \mathrm{H}, \mathrm{q}, J=7 \mathrm{~Hz},-\mathrm{OCH}_{2} \mathrm{CH}_{3}\right), 6.81(1 \mathrm{H}, \mathrm{t}, J=6.5 \mathrm{~Hz}$, active methine), $8.00\left(3 \mathrm{H}, \mathrm{d}, J=1.5 \mathrm{~Hz}\right.$, vinyl methyl) and $8.72\left(3 \mathrm{H}, \mathrm{t}, J=7 \mathrm{~Hz} \mathrm{CH}_{2} \mathrm{CH}_{3}\right)$. Anal. Calcd. for $\mathrm{C}_{16} \mathrm{H}_{18} \mathrm{O}_{4}: \mathrm{C}, 70.05 ; \mathrm{H}, 6.61$. Found: $\mathrm{C}, 70.32 ; \mathrm{H}, 6.65$. The mother liquor was chromatographed on silica gel and elution with $n$-hexane-benzene $(2: 1)$ gave $400 \mathrm{ml}$ of the yellow crystalline mass which was recrystallized from petroleum ether to furnish the naphtoquinone derivative (XXXV), mp 90-93 ${ }^{\circ} \mathrm{M}^{+} 270$. IR $\mathrm{cm}^{-1}: \nu_{\mathrm{C}=0} 1725,1670 ; v_{\mathrm{C}=\mathrm{C}} 1630,1605$. NMR $\tau: 1.54(1 \mathrm{H}, \mathrm{s}$, benzene proton), $1.75(1 \mathrm{H}, \mathrm{s}$, benzene proton), $2.50\left(1 \mathrm{H}\right.$, d.d, $J_{1}=11 \mathrm{~Hz}, J_{2}=17 \mathrm{~Hz}$, olefinic proton), $3.12(1 \mathrm{H}, \mathrm{q}, J=1.5 \mathrm{~Hz}$, olefinic proton), 4.08 $\left(1 \mathrm{H}\right.$, d.d, $J_{2}=17 \mathrm{~Hz}, J_{3}=1 \mathrm{~Hz}$, olefinic proton), $4.42\left(1 \mathrm{H}\right.$, d.d, $J_{1}=11 \mathrm{~Hz}, J_{3}=1 \mathrm{~Hz}$, olefinic proton), 5.56 $\left(2 \mathrm{H}, \mathrm{q}, J=7 \mathrm{~Hz}, \mathrm{OC}_{2} \mathrm{CH}_{3}\right), 7.80\left(3 \mathrm{H}, \mathrm{d}, J=1.5 \mathrm{~Hz}\right.$, vinyl methyl), $8.56\left(3 \mathrm{H}, \mathrm{t}, J=7 \mathrm{~Hz}, \mathrm{OCH}_{2} \mathrm{CH}_{3}\right)$. 
Hydrogenation of XXV_-A solution of $80 \mathrm{mg}$ of XXXV in $5 \mathrm{ml}$ of AcOEt was hydrogenated over $30 \mathrm{mg}$ of $10 \% \mathrm{Pd}-\mathrm{C}$. After the usual work up, recrystallization of the residue from petroleum ether gave

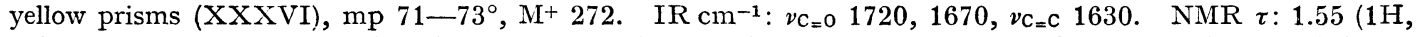
$\mathrm{s}$, benzene proton), $2.00(1 \mathrm{H}, \mathrm{s}$, benzene proton), $3.13(1 \mathrm{H}, \mathrm{q}, J=1.5 \mathrm{~Hz}$, olefinic proton), 5.56 ( $2 \mathrm{H}, \mathrm{q}$, $\left.J=7 \mathrm{~Hz}, \mathrm{OCH}_{2} \mathrm{CH}_{3}\right), 6.90\left(2 \mathrm{H}, \mathrm{q}, J=8 \mathrm{~Hz}, \mathrm{CH}_{2} \mathrm{CH}_{3}\right) 7.80(3 \mathrm{H}, \mathrm{d}, J=1.5 \mathrm{~Hz}$, vinyl methyl), $8.56(3 \mathrm{H}, \mathrm{t}$, $\left.J=7 \mathrm{~Hz}, \mathrm{OCH}_{2} \mathrm{CH}_{3}\right)$ and $8.70\left(3 \mathrm{H}\right.$, t., $\left.J=8 \mathrm{~Hz}, \mathrm{CH}_{2} \mathrm{CH}_{3}\right)$.

The Alcohol (XXVIb) - A solution of $4.2 \mathrm{~g}$ of $(\mathrm{Xb})$ in $10 \mathrm{ml}$ of DMF was added to the stirred mixture of $1.8 \mathrm{~g}$ of $\mathrm{NaH}$ (mineral oil free) in $15 \mathrm{ml}$ of DMF under ice cooling and nitrogen. After $30 \mathrm{minutes}, 5.3 \mathrm{~g}$ of $\mathrm{ClCH}_{2} \mathrm{OCH}_{3}$ was added dropwise to the reaction mixture, and the mixture was further stirred for ten minutes. Excess hydride was decomposed by addition of cold wet ether with caution and a large amount of water was added. The mixture was extracted with ether and the extract was dried over $\mathrm{K}_{2} \mathrm{CO}_{3}$ and evaporated to dryness in vacuo to yield $6.3 \mathrm{~g}$ of the oily (XXVb). To a solution of $6.3 \mathrm{~g}$ of XXVb in $50 \mathrm{ml}$ of dry ether was added $1.5 \mathrm{~g}$ of $\mathrm{LiAlH}_{4}$ little by little under cooling. After reaction mixture was refluxed for $4 \mathrm{hr}$, excess hydride was decomposed with wet ether. Organic layer was separated, dried over $\mathrm{K}_{2} \mathrm{CO}_{3}$ and evaporated. Distillation of the residue gave $5.0 \mathrm{~g}$ of the alcohol (XXVIb), bp $151.5-154^{\circ} / 3 \mathrm{mmHg}$.

5-(2-Ethoxycarbonyl-trans-vinyl)-1,4-hydroquinone (XXIXb) - To a stirred solution of $60 \mathrm{~g}$ of XXVIb in 1.01 of dry $\mathrm{CH}_{2} \mathrm{Cl}_{2}$ was added portionwise $474 \mathrm{~g}$ of $\mathrm{CrO}_{3}-2$ pyridine complex. After $2 \mathrm{hr}$, the filtrate was washed with water and dried over $\mathrm{K}_{2} \mathrm{CO}_{3}$. The solvent was evaporated in vacuo, and the residue was chromatographed on silica gel and elution with $\mathrm{CHCl}_{3}$ gave $50 \mathrm{~g}$ of the oily aldehyde (XXVIIb). IR $\mathrm{cm}^{-1}$ : $\nu \mathrm{C}=0$ 1681. To a suspension of $11 \mathrm{~g}$ of $\mathrm{NaNH}_{2}$ in $150 \mathrm{ml}$ of dry THF was added with stirring a solution of $61 \mathrm{~g}$ of phosphonate in $70 \mathrm{ml}$ of dry THF under ice cooling. Then the solution was stirred at room temperature under a slow stream of nitrogen to sweep out the evolved ammonia. After $4 \mathrm{hr}$, a solution of $50 \mathrm{~g}$ of the aldehyde (XXVIIb) in $100 \mathrm{ml}$ of dry THF was added dropwise during 20 minutes at room temperature. The reaction mixture was diluted with water and extracted with ether. After drying over $\mathrm{MgSO}_{4}$, the solvent was evaporated to leave $65 \mathrm{~g}$ of the oily $\alpha, \beta$-unsaturated ester (XXVIIIb). IR $\mathrm{cm}^{-1}: v_{\mathrm{C}=0} 1701$; ${ }^{\nu} \mathrm{C}_{\mathrm{C}} \mathrm{C}$ 1630. NMR $\tau: 2.00(1 \mathrm{H}, \mathrm{d}, J=16 \mathrm{~Hz}$, olefinic proton), $3.53(1 \mathrm{H}, \mathrm{d}, J=16 \mathrm{~Hz}$, olefinic proton), 5.73 $\left(2 \mathrm{H}, \mathrm{q}, J=7.2 \mathrm{~Hz}, \mathrm{OCH}_{2} \mathrm{CH}_{3}\right)$ and $8.67\left(3 \mathrm{H}, \mathrm{t}, J=7.2 \mathrm{~Hz}, \mathrm{OCH}_{2} \mathrm{CH}_{3}\right)$. A solution of $15.8 \mathrm{~g}$ of $\mathrm{XXVIIIb}$ in $55 \mathrm{ml}$ of $99 \% \mathrm{EtOH}$ and two droups of conc. $\mathrm{HCl}$ was refluxed for $7 \mathrm{hr}$ under nitrogen. After cooling, water was added and the mixture was extracted with ether. The extract was dried over $\mathrm{MgSO}_{4}$ and evaporated to dryness to yield $8.1 \mathrm{~g}$ of slightly yellow crystals. Recrystallization from ether gave the hydroquinone (XXIXb) as pale yellow crystals, $\mathrm{mp} 164-166^{\circ}$. IR $\mathrm{cm}^{-1}: \nu_{0-\mathrm{H}} 3318 ; v_{\mathrm{C}=0} 1680 ; v_{\mathrm{C}=\mathrm{C}} 1620$ (Nujol). Anal. Calcd. for $\mathrm{C}_{11} \mathrm{H}_{12} \mathrm{O}_{4}$ : C, 63.45; H, 5.81. Found: C, 63.27; $\mathrm{H}, 5.75$.

The Adduct (XXXIVb) A solution of $450 \mathrm{~g}$ of $\mathrm{FeCl}_{3}$ in $370 \mathrm{ml}$ of $99 \% \mathrm{EtOH}$ was added to a solution of $31.4 \mathrm{~g}$ of XXIXb in $200 \mathrm{ml}$ of $99 \% \mathrm{EtOH}$ under ice cooling. The mixture was stirred for $5 \mathrm{hr}$ and diluted with ether. The ether layer was washed with water and dried over $\mathrm{MgSO}_{4}$. Removal of the solvent left $29.4 \mathrm{~g}$ of the crude quinone (IXb). To a solution of the above quinone in $30 \mathrm{ml}$ of dry benzene was added $30 \mathrm{~g}$ of butadiene. The mixture was stirred in an autoclave at room temperature for $24 \mathrm{hr}$. Removal of the solvent and trituration of the residue with ether gave $10.4 \mathrm{~g}$ of the adduct. Recrystallization from ether gave colorless prisms, $\mathrm{mp} 97-98^{\circ}$. IR $\mathrm{cm}^{-1}: v_{\mathrm{C}=0} 1710,1688 ; v_{\mathrm{C}=\mathrm{c}} 1646$. NMR $\tau: 3.03$ $(1 \mathrm{H}, \mathrm{d}, J=16 \mathrm{~Hz}$, olefinic proton), $3.32(2 \mathrm{H}, \mathrm{s}$, olefinic protons $), 4.14(1 \mathrm{H}, \mathrm{d}, J=16 \mathrm{~Hz}$, olefinic proton), $4.25-4.33\left(2 \mathrm{H}, \mathrm{m}\right.$, olefinic proton), $5.79\left(2 \mathrm{H}, \mathrm{q}, J=7.2 \mathrm{~Hz}, \mathrm{OCH}_{2} \mathrm{CH}_{3}\right), 6.79(1 \mathrm{H}, \mathrm{t}, J=7.4 \mathrm{~Hz}$, active methine), $8.70\left(3 \mathrm{H}, \mathrm{t}, J=7.2 \mathrm{~Hz}, \mathrm{CH}_{2} \mathrm{CH}_{3}\right)$. Anal. Calcd. for $\mathrm{C}_{15} \mathrm{H}_{16} \mathrm{O}_{4}: \mathrm{C}, 69.21 ; \mathrm{H}, 6.20$. Found: C, $69.33 ; \mathrm{H}, 6.10$. 